Al-Ishlah: Jurnal Pendidikan - ISSN: 2087-949o (p); 2597-940X (e)

Vol. 11, No. 1 (2019)

\title{
PENERAPAN METODE MAKE A MATCH BERBANTU MEDIA VISUAL PADA MATERI LITOSFER UNTUK MENINGKATKAN HASIL BELAJAR SISWA
}

\author{
Reni \\ SMA N 1 Pangkalpinang \\ Email: rhenie0306@gmail.com
}

\begin{abstract}
Abstrak
This study aims to determine the effect of using the make a match method in visual media to improve student learning outcomes. This study is a classroom action research (CAR), which consists of four phases of activity, namely planning, action, observation and reflection stages for each cycle. The implementation of the activity stages is carried out in 2 cycles. The study is conducted in the even semester of the 2018/2019 school year from January to February 2019. The first cycle was held in the third and fourth weeks of January, and the second cycle was held in the fifth week of January and the first week of February. This study was conducted in class X MIPA 2 in SMA N 1 Pangkalpinang. Preliminary tests were carried out before the first training cycle and completed in order to describe the initial conditions of the students, prior to taking any action after the assignments completed with the assessment tasks by writing tests for each cycle.The results of the study show that the initial abilities of the students before starting the action were at an average value of 65 and the percentage of completeness of $35.48 \%$. At the first cycle, there was an increase in the mean value to 73, with the completeness percentage of $64.52 \%$. There were several evaluations from the first cycle, including time management, addition of intergroup discussions, and rules of the game. This evaluation was used as the basis for improvement in the cycle 2, obtaining the average value to increase to 80 and the completeness percentage reached $100 \%$. The value and completeness, as well as the student activity increased in the second cycle, from those at the first cycle. Based on these results, the study concluded that the use of make a match method combined with the visual media improved the student learning outcomes.
\end{abstract}

Penelitian ini bertujuan untuk mengetahui pengaruh penerapan metode make a match berbantu media visual terhadap peningkatan hasil belajar siswa. Jenis penelitian ini merupakan penelitian tindakan kelas (PTK) yang terdiri atas empat tahap kegiatan, yaitu tahap perencanaan, pelaksanaan tindakan, observasi, dan refleksi untuk setiap siklusnya. Pelaksanaan tahapan kegiatan dilakukan dalam 2 kali siklus. Pelaksanaan penelitian dilakukan pada semester genap tahun ajaran 2018/2019 dari bulan Januari sampai Februari 2019. Siklus pertama dilakukan pada minggu ketiga dan keempat Januari sedangkan siklus kedua dilaksanakan minggu kelima Januari dan Minggu pertama Februari. Penelitian ini dilaksanakan di kelas X MIPA 2 di SMA N 1 Pangkalpinang. Pre-tes dilakukan 
Al-Ishlah: Jurnal Pendidikan - ISSN: 2087-949o (p); 2597-940X (e)

Vol. 11, No. 1 (2019)

sebelum dilaksanakan pembelajaran siklus 1 untuk menggambarkan kondisi awal siswa sebelum mendapatkan tindakan setelah pelaksanaan kegiatan yang diakhiri dengan kegiatan evaluasi melalui tes tertulis untuk setiap siklusnya. Hasil penelitan menunjukkan kemampuan awal siswa sebelum mendapatkan tindakan nilai rata-rata 65 dan persentase ketuntasan 35,48\%. Pada siklus 1 terjadi kenaikan untuk nilai rata-rata menjadi 73 dengan persentase ketuntasan sebesar 64,52\%. Beberapa evaluasi dari siklus 1 diantaranya waktu, penambahan diskusi antar kelompok, dan peraturan permainan. Evaluasi ini dijadikan dasar perbaikan di siklus 2. Pada siklus ini terjadi kenaikan nilai rata-rata ke angka 80 dan ketuntasannya mencapai 100\%. Perubahan dari siklus 1 ke siklus 2, selain nilai dan ketuntasan diiringi pula dengan kenaikan keaktifan siswa. Disimpulkan bahwa penerapan metode make a match berbantu media visual mampu meningkatkan hasil belajar dan keaktifan siswa.

Kata Kunci: Penelitian Tindakan Kelas Geografi, Kartu Bergambar, Evaluasi Pembelajaran

\section{PENDAHULUAN}

Kajian ini bertujuan untuk mengevaluasi metode make a match dikombinasikan dengan media visual dalam pembelajaran geografi. Kombinasi metode dengan media ini jarang digunakan khususnya di Kota Pangkalpinang, Provinsi Bangka belitung. Dengan demikian hasil dari makalah ini akan sangat bermanfaat bagi para pendidik di Indonesia. Undang-Undang Nomor 20 Tahun 2003 mengenai Sistem Pendidikan Nasional pada Pasal 3 yang menjelaskan bahwa pendidikan nasional berfungsi mengembangkan kemampuan dan membentuk watak serta peradaban bangsa yang bermartabat dalam rangka mencerdaskan kehidupan bangsa, bertujuan untuk mengembangkan potensi peserta didik agar menjadi manusia yang beriman dan bertakwa kepada Tuhan Yang Maha Esa, berakhlak mulia, sehat, berilmu, cakap, kreatif, mandiri, dan menjadi warga negara yang demokratis serta bertanggung jawab. Tujuan pendidikan tersebut dijadikan sebagai arah dan landasan dalam meningkatkan kualitas pendidikan. Kualitas pendidikan dapat ditingkatkan melalui peningkatan kualitas sumber daya manusia. Permasalahan sumber daya manusia yang masih rendah menjadi masalah utama pada penerapan pendidikan di Indonesia. Kualitas sumber daya manusia yang baik dapat membawa perubahan dalam dunia pendidikan melalui kegiatan-kegiatan pembelajaran.

Pemerintah membentuk kurikulum dalam upaya pencapaian keberhasilan pembelajaran. Kurikulum 2013 merupakan kurikulum terbaru yang bertujuan untuk mempersiapkan peserta didik di Indonesia agar memiliki kemampuan hidup sebagai pribadi dan warga negara yang beriman, produktif, kreatif, inovatif, dan 
Al-Ishlah: Jurnal Pendidikan - ISSN: 2087-949o (p); 2597-940X (e)

Vol. 11, No. 1 (2019)

afektif melalui penguatan sikap, keterampilan, dan pengetahuan yang terintegrasi sehingga diharapkan mampu berkontribusi pada kehidupan bermasyarakat, berbangsa, bernegara, dan peradaban dunia.

Pendidikan dari waktu ke waktu terus melakukan inovasi sesuai dengan perkembangan peradaban dan perkembangan individu manusia. Hal inilah yang mendorong kemajuan yang pesat dalam bidang pendidikan. Perkembangan trend dunia pada abad ke-21 lebih berorientasi pada pengembangan potensi manusia dan tidak lagi memusatkan pada kemampuan individu dalam kemampuan teknik dalam melakukan eksplorasi dan eksploitasi alam. Pengembangan potensi SDM berkaitan dengan perkembangan inovasi teknologi, sehingga setiap individu yang terlibat dalam pendidikan harus dapat menyesuaikan dengan perkembangan yang ada saat ini. Kegiatan pembelajaran sangat dipengaruhi oleh inovasi tekonologi pendidikan.

Pembelajaran merupakan kegiatan yang banyak melibatkan keselarasan aktivitas siswa dan aktivitas guru. Harmonisasi aktivitas siswa dan guru diperlukan untuk mencapai tujuan pembelajaran. Alternatif metode mengajar dapat dijadikan sebagai alat untuk mencapai tujuan tersebut. Guru dalam proses pembelajaran perlu menggunakan metode mengajar yang tepat dan bervariasi untuk mencapai tujuan pembelajaran yang sudah direncanakan sebelumnya. Tujuan pembelajaran dapat tercapai dengan penggunaan metode pembelajaran yang sesuai dengan analisis kesesuaian antara tipe isi pelajaran dengan tipe kinerja (performansi).

Geografi merupakan pembelajaran yang menarik karena tidak hanya berbicara tentang manusia tetapi juga interaksi manusia dengan lingkungan baik lingkungan alam maupun lingkungan sosial. Cakupan yang dipelajari dalam geografi sangatlah luas, sehingga kurang efektif apabila siswa hanya diberikan materi-materi kemudian menghafal dan ulangan. Peningkatan pemahaman siswa terhadap mata pelajaran Geografi dapat dilakukan dengan membangun rasa ingin tahu siswa dan melibatkan siswa aktif di dalamnya. Penggalian keaktifan siswa dalam proses pembelajaran Geografi dapat dilakukan dengan penggunaan metode pembelajaran yang tepat.

Model pembelajaran kooperatif merupakan model pembelajaran yang dapat meningkatkan keterlibatan siswa dalam proses pembelajaran. Salah satu metode pembelajaran dalam model pembelajaran kooperatif adalah make a match. Metode make a match digunakan dalam pembelajaran Geografi dengan materi litosfer. Karena metode ini menyenangkan, diyakini dapat meningkatkan rasa ingin tahu siswa, dan melibatkan siswa dalam setiap tahapan aktivitasnya. Metode pembelajaran make a match dilakukan dengan cara berkelompok setelah itu kemudian, berpasangan. Berkaitan dengan hal tersebut, metode ini diharapkan 
Al-Ishlah: Jurnal Pendidikan - ISSN: 2087-949o (p); 2597-940X (e)

Vol. 11, No. 1 (2019)

dapat memudahkan siswa untuk memahami dan menerima materi yang disampaikan dan hasil yang diperoleh siswa juga meningkat.

Prinsip yang relevan dalam penciptaan lingkungan belajar bagi anak adalah pengembangan pengajaran yang menyediakan fasilitas bagi anak untuk bereksplorasi, berpikir, dan memperoleh kesempatan untuk berdiskusi, berkomunikasi, dan berinteraksi dengan orang lain (guru, teman-teman atau pihak lain). Kemampuan guru di dalam memanipulasi objek fisik menjadi objek berpikir anak, akan selalu dituntut dalam pengembangan pengajarannya. Metode make a match dapat menjembatani konsep abstrak menjadi nyata dalam pembelajaran siswa. Selain itu, metode make a match merupakan metode pembelajaran yang menyenangkan karena di dalamnya ada unsur permainan.

Rusman (2011: 223) menyebutkan bahwa teknik make a match (mencari pasangan) merupakan salah satu dari jenis model pembelajaraan kooperatif. Metode pembelajaran make a match atau yang dikenal dengan mencari pasangan dikembangkan oleh Lorna Curran tahun 1994. Salah satu keunggulan dari metode pembelajaran ini adalah siswa secara berkelompok berpasangan sambil belajar mengenali konsep atau topik dalam suasana yang menggembirakan sehingga materi yang diajarkan lebih mudah di pahami dan diingat oleh siswa. Langkahlangkah metode pembelajaran make a match yang dikemukakan oleh Lorna Curran (1994) adalah sebagai berikut:

1. Guru menyiapkan beberapa kartu yang berisi beberapa konsep atau topik yang cocok untuk sesi review, sebaliknya satu bagian kartu soal dan bagian lainnya kartu jawaban;

2. Setiap siswa mendapat satu buah kartu;

3. Tiap siswa memikirkan jawaban/soal dari kartu yang dipegang;

4. Setiap siswa mencari pasangan yang mempunyai kartu yang cocok dengan kartunya (soal jawaban);

5. Setiap siswa yang dapat mencocokkan kartunya sebelum batas waktu diberi poin;

6. Setelah satu babak kartu dikocok lagi agar tiap siswa mendapat kartu yang berbeda dari sebelumnya;

7. Demikian seterusnya;

8. Kesimpulan/penutup.

Penerapan metode make a match dalam penelitian ini menggunakan visual sehingga kartu soal pertama berupa gambar, kartu soal yang kedua berupa jawaban dan kartu soal yang ketika berupa penjelasan dari jawaban. Pada setiap paket kartu soal di akhiri dengan diskusi. Menurut Supriyono (2012), metode make a match memiliki beberapa kelebihan, diantaranya sebagai berikut.

1. Pembelajaran akan menjadi lebih menyenangkan dan siswa dapat didorong lebuh aktif; 
Al-Ishlah: Jurnal Pendidikan - ISSN: 2087-949o (p); 2597-940X (e)

Vol. 11, No. 1 (2019)

2. Materi pembelajaran yang disampaikan lebih menarik perhatian siswa;

3. Cocok untuk pemberian tugas sederhana dan dapat digunakan untuk semua mata pelajaran dan semua jenjang kelas.

Sementara, beberapa kekurangan atau kelemahan dari metode make a match yaitu sebagai berikut.

1. Perlu manajemen yang kuat karena metode ini memungkinkan terjadi keributan di kelas;

2. Diperlukan bimbingan dari guru untuk melakukan kegiatan;

3. Terkadang waktu terbuang karena siswa terlalu banyak bermain-main dalam proses pembelajaran.

Dalam pelaksanaan metode make a match tidak semua peserta didik baik yang berperan sebagai pemegang kartu pertanyaan, pemegang kartu jawaban, maupun penilai, mengetahui dan memahami secara pasti apakah betul kartu pertanyaan jawaban yang mereka pasangkan sudah cocok. Demikian halnya juga peserta didik kelompok penilai. Mereka juga belum mengetahui pasti apakah penilaian mereka benar atas pasangan pertanyaan-jawaban. Dalam menjembatani kesesuaian pertanyaan dengan jawaban siswa guru memfasilitasi diskusi untuk memberikan kesempatan kepada seluruh peserta didik mengonfirmasikan hal-hal yang telah mereka lakukan, yaitu memasangkan pertanyaan jawaban dan melaksanakan penilaian.

Metode mengajar bukan satu-satunya inovasi dalam pembelajaran. Hal yang tak kalah penting dari metode pembelajaran adalah media pembelajaran yang merupakan unsur penting dalam suatu proses pembelajaran. Pemilihan metode dalam pembelajaran mempengaruhi pemilihan media pembelajaran. Dalam pemilihan media juga harus diperhatikan kondisi sekolah serta karakteristik siswa, sehingga tujuan dari adanya pemberian media dapat terwujud. Menurut Azhar (2009: 15), media pembelajaran memiliki pengaruh dalam memberi dampak terhadap kondisi siswa, dengan kata lain, dalam menciptakan kondisi sekitar pembelajar yang kondusif.

Pembelajaran yang efektif memerlukan perencanaan yang baik. Media yang akan digunakan dalam proses pembelajaran itu juga memerlukan perencanaan yang baik. Kebanyakan guru, dosen, atau pelatih yang menggunakan media tidak mendasarkan pilihan medianya pada pemikiran logis dan ilmiah, melainkan lebih karena mengikuti perkembangan majunya teknologi atau karena mengikuti kebiasaan yang berkembang di lingkungan sekolah. Tidak sedikit juga, dalam proses belajar mengajar dikelas para pengajar membiasakan penggunaan media yang telah disediakan oleh sekolah, sehingga penggunaan media tersebut tidak didasarkan pada kesesuaian dengan tujuan, materi, dan karakteristik siswanya. 
Al-Ishlah: Jurnal Pendidikan - ISSN: 2087-949o (p); 2597-940X (e)

Vol. 11, No. 1 (2019)

Kata media berasal dari bahasa latin dan merupakan bentuk jamak dari kata medium yang secara harfiah berarti perantara atau pengantar. Menurut Sardiman (2007: 7) media adalah segala sesuatu yang dapat digunakan untuk menyalurkan pesan dari pengirim ke penerima sehingga dapat merangsang pikiran, perasaan, perhatian dan minat serta perhatian siswa sedemikian rupa sehingga proses belajar terjadi.

Media adalah sebuah alat yang mempunyai fungsi menyampaikan pesan (Bovee dalam Hujair, 2013: 3-4). Media pembelajaran adalah sebuah alat yang berfungsi dan dapat digunakan untuk menyampaikan pesan pembelajaran. Pembelajaran adalah proses komunikasi antara pembelajar, pengajar, dan bahan ajar. Maka dapat dikatakan bahwa, bentuk komunikasi tidak akan berjalan tanpa bantuan sarana untuk menyampaikan pesan. Bentuk-bentuk stimulus dapat dipergunakan sebagai media, diantaranya adalah hubungan atau interaksi manusia, realitas, gambar bergerak atau tidak, serta tulisan dan suara yang direkam. Adanya kelima bentuk stimulus ini, akan membantu pembelajar mempelajari bahan pelajaran. Dapat disimpulkan bahwa bentuk-bentuk stimulus yang dapat dipergunakan sebagai media adalah suara, penglihatan, dan gerakan (Eysink, 2009: 1110).

Menurut Azhar (2009: 15) media pembelajaran memiliki salah satu fungsi utama sebagai alat bantu mengajar yang turut mempengaruhi iklim , kondisi, dan lingkungan belajar yang ditata dan diciptakan guru. Munadi (2013: 49-52; 57) mengemukakan bahwa media dalam proses pembelajaran dapat dikelompokkan menjadi 4 kelompok besar, yaitu media audio, media visual, media audio visual, dan multimedia.

Penelitian yang telah dilakukan oleh Ismail yang berjudul meningkatkan hasil belajar siswa kelas IV sekolah dasar tentang keragaman budaya bangsaku melalui model make a match dalam pembelajaran IPS menunjukan adanya peningkatan hasil belajar siswa setelah adanya pembelajaran menggunakan metode make a match. Mengacu pada penelitian tersebut dengan disesuaikan oleh kompetensi pada mata pelajaran Geografi di SMA metode make a match dipadukan dengan media visual. Penggabungan Metode make a match dengan media visual akan dapat menambah motivasi siswa dalam pembelajan sehingga hasil belajar siswa juga akan meningkat.

Metode dan media pembelajaran merupakan aspek yang saling terkait satu sama lain, Pada proses belajar mengajar guru harus mempunyai metode atau cara yang efisien untuk menyampaikan materi dan juga harus mempunyai keahlian dalam menggunakan berbagai macam media pembelajaran, terutama media yang digunakan dalam proses mengajarnya, sehingga materi ataupun pesan yang disampaikan akan tersalurkan dengan baik pula. Penggunaan metode 
Al-Ishlah: Jurnal Pendidikan - ISSN: 2087-949o (p); 2597-940X (e)

Vol. 11, No. 1 (2019)

pembelajaran yang dipadukan dengan penggunaan media pembelajaran yang cocok dapat mempercepat tujuan dari proses pembelajaran.

Penerapan metode make a match dengan berbantu media audio visual merupakan inovasi strategi dalam pembelajaran yang belum banyak digunakan terutama di lokasi penelitian. Dengan demikian, peneliti tertarik untuk melakukan penerapan metode pembelajaran make a match berbantu media visual sebagai upaya untuk meningkatkan keaktifan hasil belajar siswa sehingga mendukung tercapainya tujuan pendidikan sebagaimana yang diamanatkan dalam undangundang. Penelitian ini mendukung teori sebelumnya dan memberikan kontribusi lanjutan untuk penelitian lebih lanjut serta memberikan manfaat praktis bagi guru dalam kegiatan pembelajaran di kelas untuk memperkaya proses pembelajaran di kelas.

\section{METODE PENELITIAN}

Penelitian ini menggunakan metode penelitian tindakan kelas (PTK). Jenis penelitian ini mampu menawarkan cara dan prosedur untuk memperbaiki dan meningkatkan profesionalisme pendidik dalam proses belajar-mengajar di kelas dengan melihat kondisi nyata siswa karena akar permasalahan yang muncul di kelas, dan dirasakan langsung oleh guru yang bersangkutan. Dalam PTK, peneliti/guru dapat melihat praktik pembelajaran atau bersama guru lain, ia dapat melakukan penelitian terhadap siswa yang dilihat dari segi aspek interaksinya dalam proses pembelajaran. Dari penjelasan tersebut dapat diartikan bahwa penelitian tindakan kelas merupakan suatu bentuk investigasi yang bersifat reflektif partisipatif, kolaboratif dan spiral, yang memiliki penerapan tindakan (observasion and evaluation), melakukan refleksi (reflecting) dan seterusnya sampai dengan perbaikan atau peningkatan yang diharapkan tercapai (Arikunto, 2015: 191-194).

Penelitian ini dilaksanakan sebanyak 2 siklus. Setiap siklus terdiri atas empat tahap kegiatan, yaitu tahap perencanaan, pelaksanaan tindakan, observasi, dan refleksi. Pada siklus dua terdapat tambahan aturan diantaranya mengenai waktu menjawab dan penegasan peran dalam setiap kelompok. Penegasan aturan dalam permainan merupakan strategi agar pembelajaran lebih efisien dan terjadi peningkatan pemahaman siswa. Siklus pelaksanaan tindakan dalam PTK tersebut dapat dilukiskan sebagai berikut. 
Al-Ishlah: Jurnal Pendidikan - ISSN: 2087-949o (p); 2597-940X (e)

Vol. 11, No. 1 (2019)

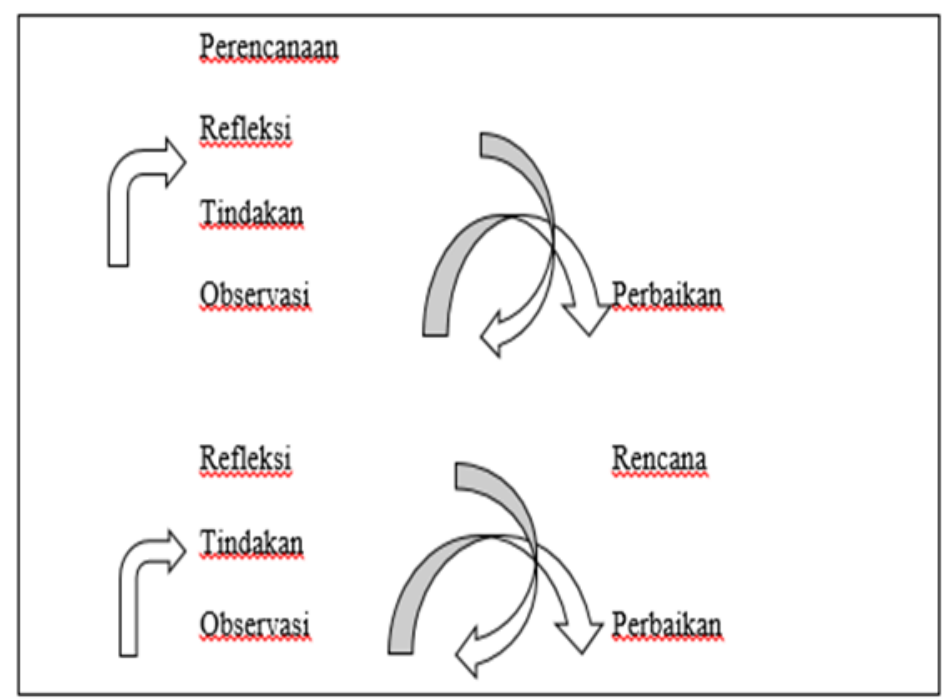

Gambar 1. Spiral Penelitian Tindakan Kelas

Pelaksanaan penelitian dilakukan pada semester genap tahun ajaran 2018/2019 dari bulan Januari sampai Februari 2019. Siklus pertama dilakukan pada minggu ketiga dan keempat Januari sedangkan siklus kedua dilaksanakan minggu kelima Januari dan minggu pertama Februari. Penelitian ini dilaksanakan di kelas X MIPA 2 di SMA N 1 Pangkalpinang. Tes tertulis merupakan data yang digunakan dalam penelitian untuk menunjukkan hasil belajar siswa. Pre-tes dilakukan sebelum dilaksanakan pembelajaran siklus 1 untuk menggambarkan kondisi awal siswa sebelum mendapatkan tindakan.

Teknik pengolahan data hasil evaluasi menggunakan pendekatan penilaian acuan patokan (PAP). Penilaian acuan patokan membandingkan apa yang dikerjakan oleh peserta didik dengan suatu kriteria atau patokan yang spesifik. Skor standar yang didapat dari hasil peserta didik diukur dengan melakukan perbandingan skor rata-rata dari setiap siklus, kemudian menghitung persentase ketuntasan belajar siswa (Arifin, 2011: 236). Pencapaian hasil belajar siswa dalam tindakan penelitian dengan melakukan perbandingan skor rata-rata dalam setiap siklus (Sudjiono, 2008: 81).

\section{HASIL DAN PEMBAHASAN}

Penelitian tindakan kelas di laksanakan dengan 2 siklus yaitu siklus pertama yang dilakukan dalam dua kali pertemuan, pada minggu ketiga dan minggu ke-empat Januari, dan siklus kedua dilaksanakan pada minggu kelima Januari dan minggu pertama Februari. Pelaksanaan di kelas X MIPA 2 pada materi litosfer mata pelajaran Geografi. Siklus pertama tentang topik bahasan 
Al-Ishlah: Jurnal Pendidikan - ISSN: 2087-949o (p); 2597-940X (e)

Vol. 11, No. 1 (2019)

tenaga endogen dan topik siklus kedua tenang tenaga eksogen. Berkaitan dengan materi yang dipilih dalam pelaksanaan metode make a match berbantu media visual ini karena berdasarkan observasi materi ini sulit dipahami siswa sehingga motivasi siswa dalam pembelajaran menjadi berkurang. Media visual dipilih karena materi ini membutuhkan banyak penayangan gambar yang kemudian dipadukan dengan metode make a match, sehingga dapat menambah keaktifan dan semangat siswa, karena metode ini adalah metode yang menyenangkan untuk diterapkan kepada siswa.

Setiap siswa membentuk kelompok. Hal ini dirangsang dalam rangka pencapaian kompetensi abad ke-21 yang salah satu diantaranya melatih bekerja sama dalam satu tim yang disebut kolaboratif. Setiap kelompok terdiri atas 6 peserta. Dalam 1 paket, ada 3 kartu, yaitu kartu soal, kartu jawaban, dan kartu penjelasan. Lima paket disiapkan untuk sekali sesi. Guru di sini berfungsi sebagai manajer atau sebagai koordinator pelaksanaan proses pembelajaran sekaligus penilai, Apabila ada kelompok yang salah, kelompok lain harus bersiap-siap membenarkannya sehingga nilainya dapat diambil oleh kelompok lain.

Sebelum pelaksaan siklus pertama dilakukan pre-tes untuk mengukur kemampuan awal siswa terhadap pemahaman suatu materi. Kemampuan awal siswa rata-rata dengan nilai 65 pada siklus pertama. Nilai rata-rata naik menjadi 73 pada siklus kedua, naik lagi menjadi 80. Dari nilai rata-rata tersebut dapat disimpulkan terjadi kenaikan nilai rata-rata dari siklus pertama ke siklus kedua. Untuk lebih jelasnya lihat gambar 2 berikut.

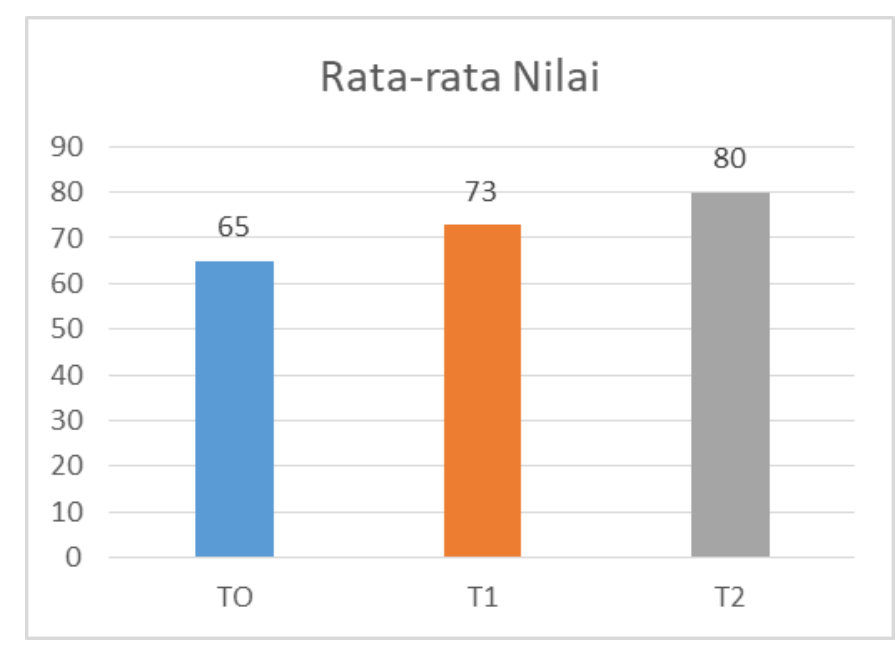

Gambar 2. Rata-rata hasil belajar siswa (pre-tes, siklus 1, siklus 2, siklus 3)

Persentase tingkat ketuntasan sebesar 35,48\% untuk pre tes atau sebelum pelaksanaan penelitian tindakan kelas sebagai langkah awal untuk mengetahui 
Al-Ishlah: Jurnal Pendidikan - ISSN: 2087-949o (p); 2597-940X (e)

Vol. 11, No. 1 (2019)

kondisi awal siswa sebelum tindakan. Persentase 35,48\% ini menunjukkan masih banyak siswa yang belum mencapai ketuntasan. Ketuntasan belajar siswa adalah 70, hal ini berdasarkan kesepakatan rapat dewan guru tahun pelajaran 2018/2019 setelah melakukan analisis baik analisis intaks, kapasitas, maupun daya dukung. Setelah pelaksanaan siklus pertama persentase ketuntasan naik menjadi $64,52 \%$. Kemudian setelah adanya evaluasi dilaksanakan siklus kedua dan hasil pada siklus kedua menunjukkan pencapaian persentase ketuntasan siswa sudah 100 persen. Ketuntasan yang $100 \%$ ini menunjukkan bahwa siswa telah menguasai indikatorindikator yang ditentukan sehingga tujuan awal yang ditetapkan sebelum pelaksanaan tindakan kelas ini tercapai. Untuk lebih jelasnya dapat dilihat pada gambar 3 berikut.

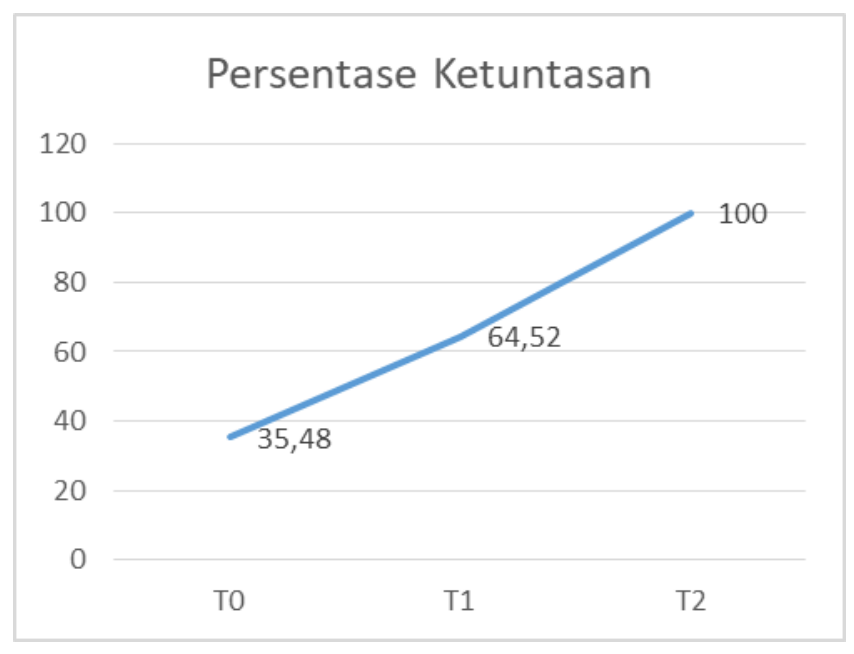

\section{Gambar 3. Rata-rata hasil belajar siswa (pre-tes, siklus 1, siklus 2, siklus 3)}

Siklus pertama rata-rata nilai 73 dengan persentase ketuntasan 64,52 ini artinya masih banyak siswa yang belum mencapai nilai KKM. Setelah dilakukan evaluasi pelaksanaan pada siklus pertama masih ada kekurangan diantaranya batasan waktu untuk tiap paket belum ditentukan dengan jelas sehingga banyak waktu yang terbuang. Siswa dalam kelompok lain berebut untuk menjawab soal sebelum diputuskan oleh penilai jawaban itu benar atau salah sehingga memicu keributan. Tidak munculnya diskusi dalam akhir permainan tiap kelompok membuat tidak adanya penguatan materi pada siklus pertama ini. Diskusi hanya sebatas dalam satu kelompok ketika mencari pasangan saja. Evaluasi siklus pertama dijadikan bahan perbaikan siklus kedua. Pada siklus kedua waktu diatur, lemparan jawaban hanya boleh dilakukan apabila kelompok tersebut oleh penilai dinyatakan salah jawabannya, serta tiap sesi dalam kelompok diakhiri dengan diskusi sebagai penguatan pemahaman siswa. Siklus kedua meunjukkan kenaikan yang signifikasi baik nilai rata-rata menjadi 80 dan ketuntasan siswa menjadi 
Al-Ishlah: Jurnal Pendidikan - ISSN: 2087-949o (p); 2597-940X (e)

Vol. 11, No. 1 (2019)

100\%. Ini dapat dilihat pada gambar 4 berikut untuk mengetahui perbandingan nilai rata-rata dan ketuntasan siswa dari pelaksanaan pre-tes, siklus 1, dan siklus 2.

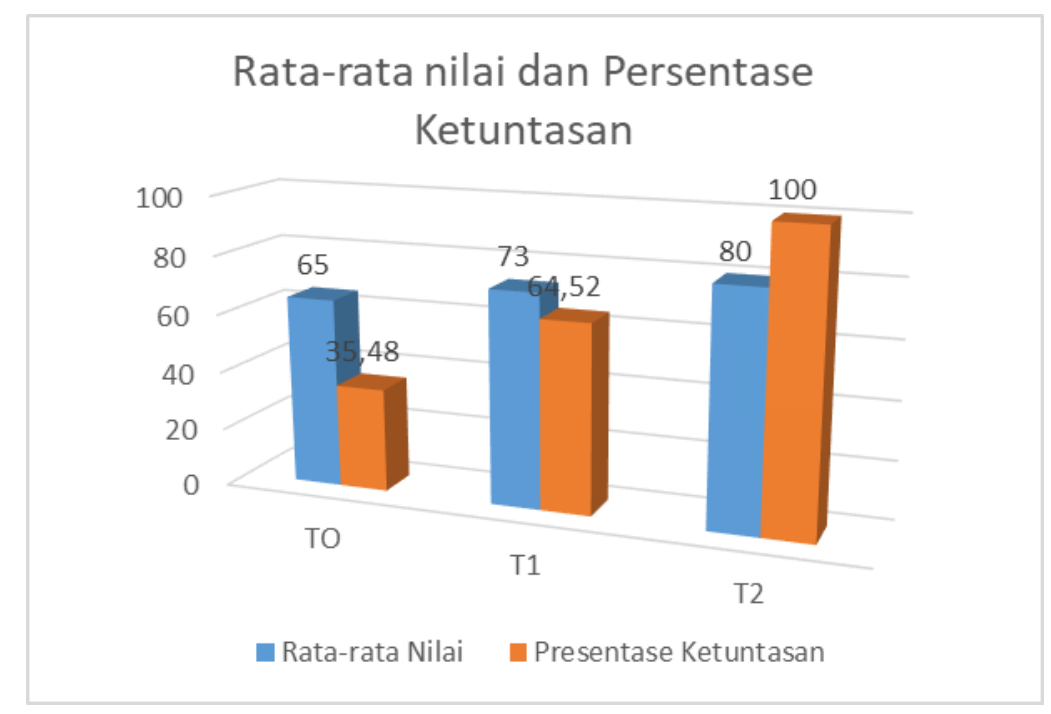

Gambar 4. Grafik rata-rata nilai dan ketuntasan hasil belajar siswa (pre-tes, siklus 1, siklus 2, siklus 3)

Kenaikan rata-rata nilai menjadi 80 dengan ketuntasan $100 \%$ pada siklus kedua menunjukkan bahwa pelaksanaan penelitian tindakan kelas sudah berhasil pada siklus kedua. Sehingga pada penelitian ini hanya ada siklus pertama dan siklus 2 .

Pelaksanaan metode make a match dikolaborasikan dengan media visual yang melibatkan aktivitas siswa. Siswa dieksplorasi untuk dapat terlibat dalam setiap aktivitas pembelajaran. Keterlibatan siswa dalam setiap aktivitas pembelajaran mampu menggali keaktifan siswa. Proses pelaksanaan pembelajaran yang telah dilakukan menunjukkan adanya peningkatan tingkat keaktifan siswa diantaranya keseriusan siswa dalam mengikuti pembelajaran (dilambangkan dengan huruf A pada grafik), keaktifan siswa dalam menjalin kerjasama dalam kelompok (dilambangkan dengan huruf B pada grafik), keaktifan siswa dalam mengikuti setiap aktivitas pembelajaran (dilambangkan dengan huruf $\mathrm{C}$ pada grafik). 
Al-Ishlah: Jurnal Pendidikan - ISSN: 2087-949o (p); 2597-940X (e)

Vol. 11, No. 1 (2019)

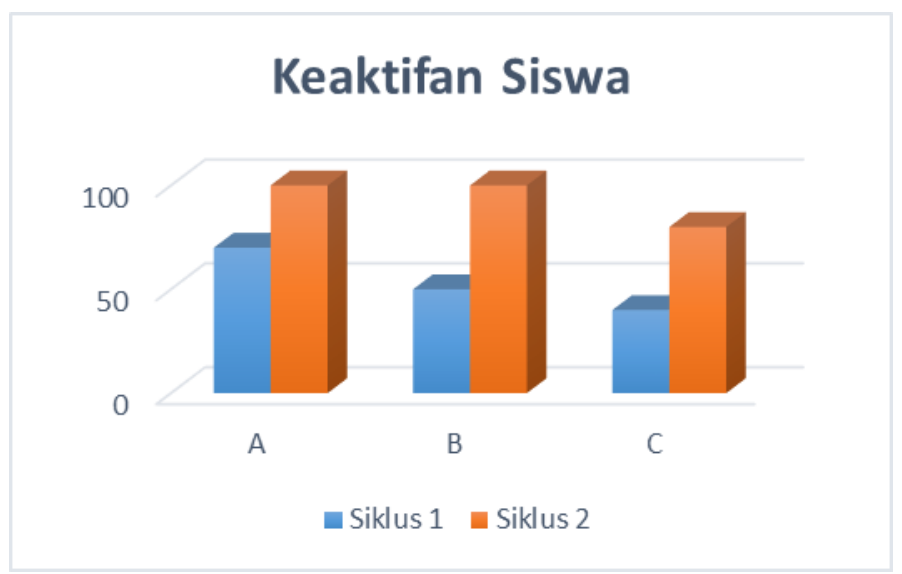

\section{Gambar 5. Grafik Keaktifan Siswa pada Siklus 1 dan Siklus 2}

Gambar grafik diatas menunjukkan keaktifan yang dilambangkan dengan huruf A naik dari 70 ke 100, indikator keatifan B dari 50 menjadi 100, poin C meningkat dari 40 ke 80 . Dari penjelasan tersebut dapat disimpulan keaktifan siswa mengalami kenaikan dari siklus 1 ke siklus 2 .

\section{SIMPULAN}

Berdasarkan hasil penelitian yang telah dilakukan dapat ditarik kesimpulan bahwa Penelitian tindakan kelas (PTK) mampu menawarkan cara dan prosedur untuk memperbaiki dan meningkatkan profesionalisme pendidik dalam proses belajar-mengajar di kelas. Mata pelajaran Geografi adalah mata pelajaran dengan bahasan yang luas dan materi litosfer dianggap materi yang sulit dipahami berdasarkan hasil observasi karena membutuhan pembelajaran yang kontekstual sehingga membutuhkan media pembelajaran yang tepat. Penggunaan metode pembelajaran memerlukan media pembelajaran sebagai daya dukung dalam proses pembelajaran. Perpaduan metode dengan media pembelajaran yang sesuai dapat saling mendukung dan menambah keaktifan dan pemahaman siswa terhadap materi. Media pembelajaran visual ternyata dapat membantu menggiring siswa ke dunia nyata yang ditambah dengan metode make a match pembelajaran dapat lebih menyenangkan sehingga mampu meningkatkan keaktifan, motivasi dan hasil pembelajaran siswa.

\section{DAFTAR PUSTAKA}

Arifin, Z. (2011). Evaluasi Pembelajaran: Prinsip, Teknik, Prosedur. Bandung: PT Remaja Rosda Karya. 
Al-Ishlah: Jurnal Pendidikan - ISSN: 2087-949o (p); 2597-940X (e)

Vol. 11, No. 1 (2019)

Arikunto, S. (2015). Penelitian Tindakan Kelas. Jakarta: PT. Bumi Aksara.

Azhar, A. (2009). Media pembelajaran. Jakarta: PT Raja Grafindo Persada.

Eysink, T.H.S. (2009). Learner Performance in Multimedia Learning Arrangements: An Analysis across Instructional Approaches. American Educational Research Journal, 46(4), 1107-1149. Retrieved from http://www.jstor.org/stable/40284748.

Hujair A.H. (2013). Media Pembelajaran Interaktif-Inovatif. Yogyakara: Kaukaba Dipantara.

Ismail. (2015). Meningkatkan Hasil Belajar Siswa Kelasw IV Sekolah Dasar tentang Keragaman Budaya Bangsaku melalui Model Make a Match Dalam Pembelajaran IPS. Jurnal Universitas Pendidikan Indonesia, Vol. VI. No. 3 April 2015.

Munadhi, Y. (2013). Media Pembelajaran Sebuah Pendekatan Baru. Jakarta: REFERENSI.

Republik Indonesia. (2003). Undang-Undang RI Nomor 20, Tahun 2003, Tentang Sistem Pendidikan Nasional.

Rusman. (2011). Model-Model Pembelajaran Mengembangkan Profesionalisme Guru. Jakarta: PT. Raja Grafindo Persada.

Sudjiono, A. (2008). Pengantar Standar Pendidikan. Jakarta: PT. Raja Grafindo.

Suprijono, A. (2012). Cooperative Laerning Teori dan Aplikasi PAIKEM. Yogyakarta: Pustaka Pelajar. 